\title{
Presacral Ganglioneuroma: Diagnostic Considerations and Therapeutic Strategy
}

\author{
Konstantinos Vardas ${ }^{\mathrm{a}} \quad$ Dimitrios Manganas $^{\mathrm{a}}$ Georgios Papadimitriou $^{\mathrm{a}}$ \\ Vasileios Vougas $^{\mathrm{a}} \quad$ Athanasios Bakalis $^{\mathrm{a}}$ Maria Chantziara ${ }^{\mathrm{b}}$ \\ Dimitrios Exarhos $^{c} \quad$ Spiros Drakopoulos ${ }^{a}$ \\ ${ }^{a}$ First Department of Surgery and Transplant Unit, ${ }^{b}$ Department of Pathology, and \\ 'Department of Radiology, Evaggelismos General Hospital, Athens, Greece
}

\section{Key Words}

Ganglioneuroma $\cdot$ Presacral ganglioneuroma $\cdot$ Retrorectal tumors

\begin{abstract}
Presacral ganglioneuroma is an extremely rare tumor of neural crest origin. To the best of our knowledge, less than 20 cases have been reported previously. The present study reports on a presacral ganglioneuroma, $10.5 \times 8 \times 4 \mathrm{~cm}$ in size, that was found incidentally in a 35year-old man with prior history of diverticulitis. He was admitted to our hospital due to lower left abdominal pain. Abdominal computed tomography and magnetic resonance imaging confirmed the extension of the lesion from the S2 level to the coccyx. The mass had low signal intensity on T1-weighted images and heterogeneous high signal intensity on T2weighted images with no intraspinal or rectal extension. T2-weighted images demonstrated a compartmentalized solid tumor with cystic components. Complete tumor resection with free surgical margins was achieved using an abdominal approach. The patient remains asymptomatic 2 years after surgery. We emphasize on clinical features, radiologic appearance and surgical treatment of this rare entity. The clinical and pathologic features of previously reported studies are also briefly reviewed.

(c) 2013 S. Karger AG, Basel
\end{abstract}

\section{Introduction}

Ganglioneuroma (GN) is a benign, slow growing and rare tumor of neural crest origin. GN may develop as a result of progressive maturation of more primitive lesions, such as

Konstantinos Vardas, MD, MSC

General Surgeon

68 Chrisanthemon STR, Zografou

GR-15772 Athens (Greece)

E-Mail costas_vardas@yahoo.gr 
Vardas et al.: Presacral Ganglioneuroma: Diagnostic Considerations and Therapeutic Strategy

neuroblastoma, or may be diagnosed as primary GN $[1,2]$. It can be found anywhere along the sympathetic nerve chain, and the most common locations are the posterior mediastinum (41.5\%), retroperitoneum (37.5\%), adrenal gland (21\%) and neck (8\%) [3]. A presacral location of GN is extremely rare. Here, we present the case of a 35-year-old man with a presacral GN $(10.5 \times 8 \times 4 \mathrm{~cm}$ in size $)$ and prior history of diverticulitis.

\section{Case Report}

A 35-year-old man presented to our hospital due to mild lower left abdominal pain lasting for 2 weeks. He reported one episode of uncomplicated diverticulitis 5 years ago, and his past medical history was unremarkable. He did not suffer from back pain or other neurologic symptoms and was physically active. Changes in bowel habits were not present. Routine blood tests, serum tumor markers (carcinoembryonic antigen, cancer antigen 19-9, and cancer antigen 125), $\alpha$-fetoprotein and plasma and urine catecholamines were within normal range.

Abdominal ultrasonography incidentally revealed a huge solid pelvic mass, with welldefined borders. Abdominal computed tomography (CT) confirmed the presence of a wellcircumscribed solid tumor in the presacral region, measuring $10 \times 8.5 \mathrm{~cm}$ in size and presenting smooth edges and no calcifications (fig. 1). Pelvic magnetic resonance imaging (MRI) confirmed the extension of the lesion from the S2 level to the coccyx (fig. 2). The mass had low signal intensity on T1-weighted images and heterogeneous high signal intensity on T2-weighted images with no intraspinal or rectal extension. In addition, we were able to demonstrate by $\mathrm{T} 2$-weighted images that it was a compartmentalized solid tumor with cystic components (fig. 3). Colonoscopy examination revealed the presence of diverticulum in the sigmoid colon without inflammation and tumor involvement of the rectum.

The patient was submitted to surgical laparotomy without a preoperative fine-needle biopsy (FNA). An abdominal approach was used with the patient in the modified LloydDavies position. The lesion was approached transperitoneally with presacral mobilization of the rectum, and complete tumor resection with free surgical margins was achieved. The specimen included a tumor of $10 \times 8.5 \times 4 \mathrm{~cm}$ in size, surrounded by a thin fibrous capsule, with elastic consistency, a compact form, and a grayish and partially brownish color.

After microscopic examination and immunohistochemical study, the diagnosis of mature GN was established. The neoplasm contained mature ganglion cells and Schwann cells together with collagen (fig. 4). Ganglion cells were distributed diffusely throughout the tumor or arranged in small clusters. There was no neuroblastomatous component. Mitoses were very rare. The immunophenotype of the neoplasm was as follows: synaptophysin $(+)$, neuron-specific enolase (+), S-100 (+), neurofilaments (+), vasoactive intestinal polypeptide $(+)$, protein $27(+)$, myeline basic protein $(-)$, and epithelial membrane antigen $(-)$. The index of cellular proliferation ki- 67 was $<1 \%$.

The patient had an uneventful recovery and was discharged on the 12th postoperative day. Repeat MRI at 12 and 24 months after surgery and neurologic examination were unremarkable.

\section{Discussion}

In adults, presacral tumors are uncommon lesions with an incidence rate of approximately 1/40,000 admissions [4]. They are derived from a variety of embryologic origins, 
Vardas et al.: Presacral Ganglioneuroma: Diagnostic Considerations and Therapeutic Strategy

may be congenital or acquired and can be classified as congenital, inflammatory, neurogenic, osseous or miscellaneous [5]. Even though the majority of these lesions are benign, malignant tumors can be also found in the presacral-retrorectal space. GN is a benign tumor of neural crest origin that is very rarely found in the presacral space with less than 20 cases reported in the literature so far (table 1).

GN of the peripheral nervous system was first described in 1870 [6]. The classification of neuroblastic tumors is based on the International Neuroblastoma Pathology Classification System (the Shimada system) that was established in 1999 [7]. According to this classification, neuroblastoma, ganglioneuroblastoma and ganglioneuroma are subdivided in seven categories based on morphologic features with the objective of proposing a prognostically significant system. Neuroblastoma, ganglioneuroblastoma and GN are tumors arising from precursor cells of the neural crest that form the sympathetic nervous system and are called neuroblastic tumors [7]. The basic difference of these subtypes, that explains their various clinical behavior and their subsequent prognosis, is the degree of differentiation of their precursor cells $[7,8]$. GN includes mature sympathetic ganglion cells and Schwannian stroma without neuroblasts or intermediate cells, neuroblastoma includes immature elements (primitive neuroblasts), and ganglioneuroblastoma has an intermediate cell population with both mature and immature cells $[7,8]$. Subsequently, they are all considered as different maturational steps of a unique neoplasm. Neuroblastoma is the least differentiated malignant lesion with unfavorable prognosis, while GN is considered a benign tumor with excellent prognosis [9]. Neuroblastoma is often lethal, but $30 \%$ of patients have favorable outcomes, and this is explained by its unique biologic features of spontaneous regression and maturation to GN in a few cases [10]. Therefore, GN may present as a primary tumor or may be the result of progressive maturation of neuroblastoma or ganglioneuroblastoma, spontaneously or after chemotherapy or radiotherapy treatment [1].

GNs are equally distributed between males and females (1.13:1) [3]. They are often asymptomatic, but a variety of nonspecific symptoms have been attributed to local mass effects on adjacent structures. Especially, for presacral GNs, low back and leg pain, bilateral hip pain, constipation, amenorrhea and neurogenic bladder have been reported in various studies as main symptoms [6,11-14]. Moreover, patients with GN (approx. 39\%) may have increased levels of catecholamines in plasma or urine, due to hormonally active tumors, and may present with symptoms as hypertension or flushing [3]. For GN, median age at diagnosis is 6.5 years. For presacral location, median age at diagnosis is 35.5 years with a range from 8 to 70 years $[3,11]$. Usually, presacral GNs have a mean diameter of $7 \mathrm{~cm}[11]$.

MRI and CT are the preferred methods for imaging of GNs. At CT, calcifications have been found in approximately $42-60 \%$ of GN. Although GN tends to be relatively homogeneous, the imaging characteristics of GN are similar to ganglioneuroblastoma and neuroblastoma, and therefore, a safe discrimination of these three tumors is not possible [8]. FNA can be used preoperatively, but it usually leads to inaccurate diagnosis. In the largest published series of five presacral GNs [14], the diagnosis of GN was not established preoperatively in any case, even though FNA biopsy was conducted in 3 patients. We did not perform FNA preoperatively because we agree that for retrorectal tumors a biopsy is required only if it will alter management and is therefore unnecessary if preoperative imaging provides sufficient information to allow appropriate surgical management [15]. Surgical resection is the optimal treatment of retrorectal tumors and provides a definitive histologic diagnosis [15].

Surgical management of retrorectal tumors includes three different approaches. The perineal approach that is performed with the patient in the Jack-Knife position, the abdominal approach, and the combined approach that includes both a laparotomy and sacral 


\begin{tabular}{l|l}
\hline DOI: $10.1159 / 000356707$ & $\begin{array}{l}\text { C } 2013 \text { S. Karger AG, Basel } \\
\text { www.karger.com/cro }\end{array}$ \\
\hline
\end{tabular}

Vardas et al.: Presacral Ganglioneuroma: Diagnostic Considerations and Therapeutic Strategy

transection [15]. Even though these lesions are rare, excision in many cases is technically demanding, and specific algorithms have been published in order to minimize complications. According to these, all lesions above the S3 level should be excised by means of an abdominal approach [15-17]. Below the middle of the S3 level, a posterior or combined approach is the ideal treatment, unless there is involvement of the pelvic viscera [15]. In cases of pelvic viscera involvement, abdominal approach with en block excision of the involved viscera is the treatment of choice. In our case, the lesion extended from the S2 level to the coccyx, and we achieved complete tumor resection via an abdominal approach in accordance to the previously published data.

Prognosis after surgical resection of GN, even if it is subtotal and there are macroscopic residuals, seems to be excellent. Adjuvant chemotherapy or radiotherapy is not indicated due to the benign nature of the disease $[3,11,12]$. Nevertheless, spontaneous malignant transformation of GN can be found in rare cases, so annual follow-up, that includes neurologic examination and pelvic magnetic imaging, is needed $[11,18]$.

\section{Disclosure Statement}

The authors declare that they have no conflicts of interest to disclose.

\section{References}

1 Hayes FA, Green AA, Rao BN: Clinical manifestations of ganglioneuroma. Cancer 1989;63:1211-1214.

-2 Przkora R, Perez-Canto A, Ertel W, Heyde CE: Ganglioneuroma: primary tumor or maturation of a suspected neuroblastoma? Eur Spine J 2006;15:363-365.

-3 Geoerger B, Hero B, Harms D, Grebe J, Scheidhauer K, Berthold F: Metabolic activity and clinical features of primary ganglioneuromas. Cancer 2001;91:1905-1913.

4 Buchs N, Taylor S, Roche B: The posterior approach for low retrorectal tumors in adults. Int J Colorectal Dis 2007;22:381-385.

5 Hobson KG, Ghaemmaghami V, Roe JP, Goodnight JE, Khatri VP: Tumors of the retrorectal space. Dis Colon Rectum 2005;48:1964-1974.

6 Leeson MC, Hite M: Ganglioneuroma of the sacrum. Clin Orthop Relat Res 1989;102-105.

7 Shimada H, Ambros IM, Dehner LP, Hata J, Joshi VV, Roald B, Stram DO, Gerbing RB, Lukens JN, Matthay KK, Castleberry RP: The International Neuroblastoma Pathology Classification (the Shimada system). Cancer 1999;86:364-372.

-8 Lonergan GJ, Schwab CM, Suarez ES, Carlson CL: Neuroblastoma, ganglioneuroblastoma, and ganglioneuroma: radiologic-pathologic correlation. Radiographics 2002;22:911-934.

-9 Guzin K, Afsar S, Yigit A, Eren SA, Ozerden E, Kanadikirik F: Pelvic ganglioneuroma. Int J Gynecol Cancer 2008;18:553-556.

10 Ambros IM, Zellner A, Roald B, Amann G, Ladenstein R, Printz D, Gadner H, Ambros PF: Role of ploidy, chromosome 1p, and Schwann cells in the maturation of neuroblastoma. N Engl J Med 1996;334:15051511.

11 Cerullo G, Marrelli D, Rampone B, Miracco C, Caruso S, Di Martino M, Mazzei MA, Roviello F: Presacral ganglioneuroma: a case report and review of literature. World J Gastroenterol 2007;13:2129-2131.

12 Roganović J: Pelvic ganglioneuroma - case report. Coll Antropol 2010;34:683-685.

-13 Okai T, Minamoto T, Ohtsubo K, Takahashi Y, Kitagata H, Kadoya M, Oda Y, Sawabu N: Presacral ganglioneuroma arising in an elderly man with persistent constipation. Abdom Imaging 2001;26:215-217.

14 Modha A, Paty P, Bilsky MH: Presacral ganglioneuromas. Report of five cases and review of the literature. J Neurosurg Spine 2005;2:366-371.

15 Woodfield JC, Chalmers AG, Phillips N, Sagar PM: Algorithms for the surgical management of retrorectal tumours. Br J Surg 2008;95:214-221.

16 Buchs N, Taylor S, Roche B: The posterior approach for low retrorectal tumors in adults. Int J Colorectal Dis 2007;22:381-385.

17 Macafee DA, Sagar PM, El-Khoury T, Hyland R: Retrorectal tumours: optimization of surgical approach and outcome. Colorectal Dis 2012;14:1411-1417. 


\begin{tabular}{l|l}
\hline Case Rep Oncol 2013;6:561-568 \\
\hline DOI: 10.1159/000356707 & $\begin{array}{l}\text { @ 2013 S. Karger AG, Basel } \\
\text { www.karger.com/cro }\end{array}$ \\
\hline
\end{tabular}

Vardas et al.: Presacral Ganglioneuroma: Diagnostic Considerations and Therapeutic Strategy

18 Ghali VS, Gold JE, Vincent RA, Cosgrove JM: Malignant peripheral nerve sheath tumor arising spontaneously from retroperitoneal ganglioneuroma: a case report, review of the literature, and immunohistochemical study. Hum Pathol 1992;23:72-75.

19 MacCarty CS, Waugh JM, Coventry MB, Cope WF Jr: Surgical treatment of sacral and presacral tumors other than sacrococcygeal chordoma. J Neurosurg 1965;22:458-464.

-20 Andersen HJ, Hansen LG, Lange P, Teglbjaerg PS: Presacral ganglioneuroma. Case report. Acta Chir Scand 1986;152:777-778.

-21 Richardson RR, Reyes M, Sanchez RA, Torres H, Vela S: Ganglioneuroma of the sacrum. A case report. Spine (Phila Pa 1976) 1986;11:87-89.

22 Stener B: Complete removal of vertebrae for extirpation of tumors. A 20-year experience. Clin Orthop Relat Res 1989;72-82.

23 Spirnak JP, Wood BP: Radiological cases of the month. Presacral ganglioneuroma. Am J Dis Child 1993;147:1119-1120.

24 Lam CH, Nagib MG: Nonteratomatous tumors in the pediatric sacral region. Spine (Phila Pa 1976) 2002;27:E284-E287.

-25 Marmor E, Fourney DR, Rhines LD, Skibber JM, Fuller GN, Gokaslan ZL: Sacrococcygeal ganglioneuroma. J Spinal Disord Tech 2002;15:265-268.

-26 Mounasamy V, Thacker MM, Humble S, Azouz ME, Pitcher JD, Scully SP, Temple HT, Eismont F: Ganglioneuromas of the sacrum - a report of two cases with radiologic-pathologic correlation. Skeletal Radiol 2006;35:117-121. 
Vardas et al.: Presacral Ganglioneuroma: Diagnostic Considerations and Therapeutic Strategy

Table 1. GN cases reviewed

\begin{tabular}{|c|c|c|c|c|c|c|c|c|}
\hline $\begin{array}{l}\text { First author, } \\
\text { year }\end{array}$ & Age & Sex & Size & CT/MRI findings & Symptoms & Surgical approach & Resection & Follow-up \\
\hline $\begin{array}{l}\text { MacCarty, } \\
1965 \text { [19] }\end{array}$ & 37 & M & $\begin{array}{l}6 \mathrm{~cm} \text { in } \\
\text { diameter }\end{array}$ & No data & Pain & $\begin{array}{l}\text { Midline sacral } \\
\text { incision, } \\
\text { coccygectomy and } \\
\text { rectum mobilization }\end{array}$ & Complete & $\begin{array}{l}\text { Asymptomatic } \\
\text { after } 9 \text { years }\end{array}$ \\
\hline $\begin{array}{l}\text { Andersen, } \\
1986[20]\end{array}$ & 14 & $\mathrm{M}$ & No data & No data & $\begin{array}{l}\text { Pain -coexistence } \\
\text { of acute } \\
\text { appendicitis }\end{array}$ & $\begin{array}{l}\text { Transperitoneal } \\
\text { approach }\end{array}$ & Subtotal & $\begin{array}{l}\text { Asymptomatic } \\
\text { after } 2 \text { years }\end{array}$ \\
\hline $\begin{array}{l}\text { Richardson, } \\
1986[21]\end{array}$ & 71 & $\mathrm{M}$ & No data & $\begin{array}{l}\text { Low-density lesion } \\
\text { in the midsacral } \\
\text { level with a sclerotic } \\
\text { margin }\end{array}$ & $\begin{array}{l}\text { Neurogenic } \\
\text { bladder, } \\
\text { constipation }\end{array}$ & $\begin{array}{l}\text { Sacral laminectomy, } \\
\text { a second surgery } \\
\text { followed which was } \\
\text { not specified }\end{array}$ & $\begin{array}{l}\text { Subtotal, } \\
\text { second } \\
\text { surgery }\end{array}$ & $\begin{array}{l}\text { Volvulus of the } \\
\text { cecum } \\
\text { postoperatively, } \\
\text { improved } \\
\text { urination } \\
\text { afterwards }\end{array}$ \\
\hline $\begin{array}{l}\text { Leeson, } \\
1989[6]\end{array}$ & 21 & $\mathrm{M}$ & No data & $\begin{array}{l}\text { Widening of the } \\
\text { right sacral foramen }\end{array}$ & $\begin{array}{l}\text { Dysuria, left leg } \\
\text { numbness }\end{array}$ & $\begin{array}{l}\text { Transperitoneal } \\
\text { approach }\end{array}$ & $\begin{array}{l}\text { Subtotal, } \\
\text { second } \\
\text { surgery }\end{array}$ & $\begin{array}{l}\text { years } \\
\text { asymptomatic }\end{array}$ \\
\hline $\begin{array}{l}\text { Stener, } \\
1989[22] \\
\end{array}$ & 20 & $\mathrm{~F}$ & No data & No data & Pain & $\begin{array}{l}\text { S2 to S3 sacral } \\
\text { amputation }\end{array}$ & Complete & $\begin{array}{l}\text { Asymptomatic } \\
\text { after } 20 \text { years }\end{array}$ \\
\hline $\begin{array}{l}\text { Spirnak, } \\
1993 \text { [23] }\end{array}$ & 8 & $\mathrm{M}$ & $\begin{array}{l}13 \times 8 \times \\
5 \mathrm{~cm}\end{array}$ & $\begin{array}{l}\text { Low-density } \\
\text { presacral mass }\end{array}$ & $\begin{array}{l}\text { Progressive } \\
\text { constipation }\end{array}$ & No data & $\begin{array}{l}\text { Complete } \\
\text { resection }\end{array}$ & Asymptomatic \\
\hline $\begin{array}{l}\text { Okai, } \\
2001[13]\end{array}$ & 70 & $\mathrm{M}$ & $\begin{array}{l}9 \times 5 \times \\
4 \mathrm{~cm}\end{array}$ & $\begin{array}{l}\text { Inhomogeneous } \\
\text { lesion with } \\
\text { calcifications }\end{array}$ & $\begin{array}{l}\text { Constipation, } \\
\text { right flank pain, } \\
\text { weight loss }\end{array}$ & $\begin{array}{l}\text { Transperitoneal } \\
\text { approach }\end{array}$ & Complete & $\begin{array}{l}\text { Mild constipation } \\
\text { persisted }\end{array}$ \\
\hline $\begin{array}{l}\text { Lam, } \\
2002[24]\end{array}$ & 11 & $\mathrm{M}$ & No data & $\begin{array}{l}\text { Extension of the } \\
\text { lesion from S1 to S5 }\end{array}$ & $\begin{array}{l}\text { Constipation, } \\
\text { back pain }\end{array}$ & $\begin{array}{l}\text { Combined anterior } \\
\text { and posterior } \\
\text { approach }\end{array}$ & Complete & $\begin{array}{l}\text { Asymptomatic } \\
\text { after } 4 \text { years }\end{array}$ \\
\hline $\begin{array}{l}\text { Marmor, } \\
2002[25]\end{array}$ & 70 & $\mathrm{~F}$ & $\begin{array}{l}6 \times 5.5 \times \\
6 \mathrm{~cm}\end{array}$ & No data & None & $\begin{array}{l}\text { Posterior approach, } \\
\text { en block excision } \\
\text { with distal sacrum } \\
\text { and coccyx }\end{array}$ & Complete & No data \\
\hline \multirow[t]{5}{*}{$\begin{array}{l}\text { Modha, } \\
2005 \text { [14] }\end{array}$} & 65 & $\mathrm{~F}$ & $9 \times 3 \mathrm{~cm}$ & $\begin{array}{l}\text { Extension of the } \\
\text { lesion laterally from } \\
\text { S1 to S2 }\end{array}$ & $\begin{array}{l}\text { Bilateral } \\
\text { hip pain }\end{array}$ & $\begin{array}{l}\text { Retroperitoneal } \\
\text { approach }\end{array}$ & Subtotal & $\begin{array}{l}2 \text { years } \\
\text { asymptomatic }\end{array}$ \\
\hline & $\overline{21}$ & $\mathrm{~F}$ & $12 \times 7 \mathrm{~cm}$ & $\begin{array}{l}\text { Extension of the } \\
\text { lesion laterally from } \\
\text { S2 to S3 }\end{array}$ & Severe flank pain & $\begin{array}{l}\text { Retroperitoneal } \\
\text { approach }\end{array}$ & Subtotal & $\begin{array}{l}2 \text { years no } \\
\text { recurrence, } \\
\text { chronic foot pain }\end{array}$ \\
\hline & 21 & M & $5 \mathrm{~cm}$ & $\begin{array}{l}\text { Extension of the } \\
\text { lesion laterally from } \\
\text { S1 to S2 }\end{array}$ & Asymptomatic & $\begin{array}{l}\text { Transperitoneal } \\
\text { approach }\end{array}$ & Subtotal & $\begin{array}{l}3 \text { years no } \\
\text { recurrence, } \\
\text { chronic foot pain }\end{array}$ \\
\hline & 19 & $\mathrm{~F}$ & $8 \mathrm{~cm}$ & $\begin{array}{l}\text { Extension of the } \\
\text { lesion into the } \\
\text { midline from S2 to } \\
\text { S3 }\end{array}$ & $\begin{array}{l}\text { Constipation and } \\
\text { low back pain }\end{array}$ & $\begin{array}{l}\text { Transperitoneal } \\
\text { approach }\end{array}$ & Complete & $\begin{array}{l}18 \text { months } \\
\text { asymptomatic }\end{array}$ \\
\hline & 28 & $\mathrm{~F}$ & No data & $\begin{array}{l}\text { Extension of the } \\
\text { lesion into the } \\
\text { midline from S2 to } \\
\text { S3 }\end{array}$ & Low back pain & $\begin{array}{l}\text { Transperitoneal } \\
\text { approach }\end{array}$ & Subtotal & $\begin{array}{l}6 \text { years } \\
\text { asymptomatic }\end{array}$ \\
\hline $\begin{array}{l}\text { Przkora, } \\
2005 \text { [2] }\end{array}$ & 17 & $\mathrm{~F}$ & No data & $\begin{array}{l}\text { Extension of the } \\
\text { lesion from S2 to S3 }\end{array}$ & $\begin{array}{l}\text { Amenorrhea, } \\
\text { weight loss }\end{array}$ & $\begin{array}{l}\text { Posterior approach, } \\
\text { partial resection of } \\
\text { the sacrum, } \\
\text { laminectomy }\end{array}$ & Complete & $\begin{array}{l}2 \text { years } \\
\text { asymptomatic }\end{array}$ \\
\hline $\begin{array}{l}\text { Cerullo, } \\
2005 \text { [11] }\end{array}$ & 64 & $\mathrm{M}$ & $\begin{array}{l}12 \times 9 \times \\
8 \mathrm{~cm}\end{array}$ & $\begin{array}{l}\text { Inhomogeneous } \\
\text { mass extending } \\
\text { from S2 to S3 }\end{array}$ & Asymptomatic & $\begin{array}{l}\text { Transperitoneal } \\
\text { approach }\end{array}$ & Complete & $\begin{array}{l}8 \text { months } \\
\text { asymptomatic }\end{array}$ \\
\hline \multirow[t]{2}{*}{$\begin{array}{l}\text { Mounasamy, } \\
2006[26]\end{array}$} & 64 & $\mathrm{M}$ & $\begin{array}{l}13.5 \times \\
8.2 \times \\
5.6 \mathrm{~cm}\end{array}$ & $\begin{array}{l}\text { Extension of the } \\
\text { lesion from S1 to S4 }\end{array}$ & $\begin{array}{l}\text { Low back pain, } \\
\text { right posterior } \\
\text { thigh pain }\end{array}$ & $\begin{array}{l}\text { Transperitoneal } \\
\text { approach and } \\
\text { laminectomy }\end{array}$ & Complete & $\begin{array}{l}12 \text { months } \\
\text { asymptomatic }\end{array}$ \\
\hline & 21 & $\mathrm{~F}$ & $\begin{array}{l}10 \times 8 \times \\
7 \mathrm{~cm}\end{array}$ & $\begin{array}{l}\text { Partially cystic, } \\
\text { heterogeneous mass }\end{array}$ & Asymptomatic & $\begin{array}{l}\text { Transperitoneal } \\
\text { approach and } \\
\text { laminectomy }\end{array}$ & Subtotal & $\begin{array}{l}4 \text { years } \\
\text { asymptomatic }\end{array}$ \\
\hline $\begin{array}{l}\text { Roganovic, } \\
2010 \text { [12] }\end{array}$ & 12 & $\mathrm{~F}$ & $\begin{array}{l}9 \times 8 \times \\
7 \mathrm{~cm}\end{array}$ & $\begin{array}{l}\text { Presence of } \\
\text { calcifications, } \\
\text { heterogeneous mass }\end{array}$ & $\begin{array}{l}\text { Lower abdominal } \\
\text { pain }\end{array}$ & $\begin{array}{l}\text { Transperitoneal } \\
\text { approach }\end{array}$ & Complete & $\begin{array}{l}3 \text { years } \\
\text { asymptomatic }\end{array}$ \\
\hline
\end{tabular}




\section{Case Reports in Oncology}

\begin{tabular}{l|l}
\hline Case Rep Oncol 2013;6:561-568 \\
\hline DOI: 10.1159/000356707 & $\begin{array}{l}\text { C 2013 S. Karger AG, Basel } \\
\text { www.karger.com/cro }\end{array}$ \\
\hline
\end{tabular}

Vardas et al.: Presacral Ganglioneuroma: Diagnostic Considerations and Therapeutic Strategy

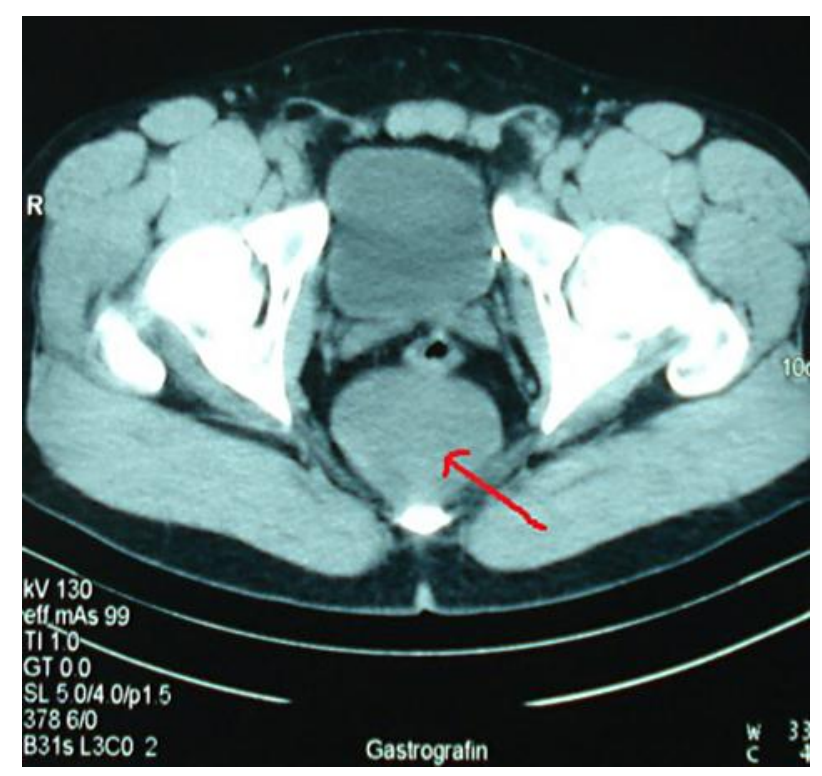

Fig. 1. Axial CT image of the lower pelvis. A well-circumscribed solid tumor is seen in the presacral region, with no signs of infiltration, in contact with the posterior wall of the rectum (arrow).

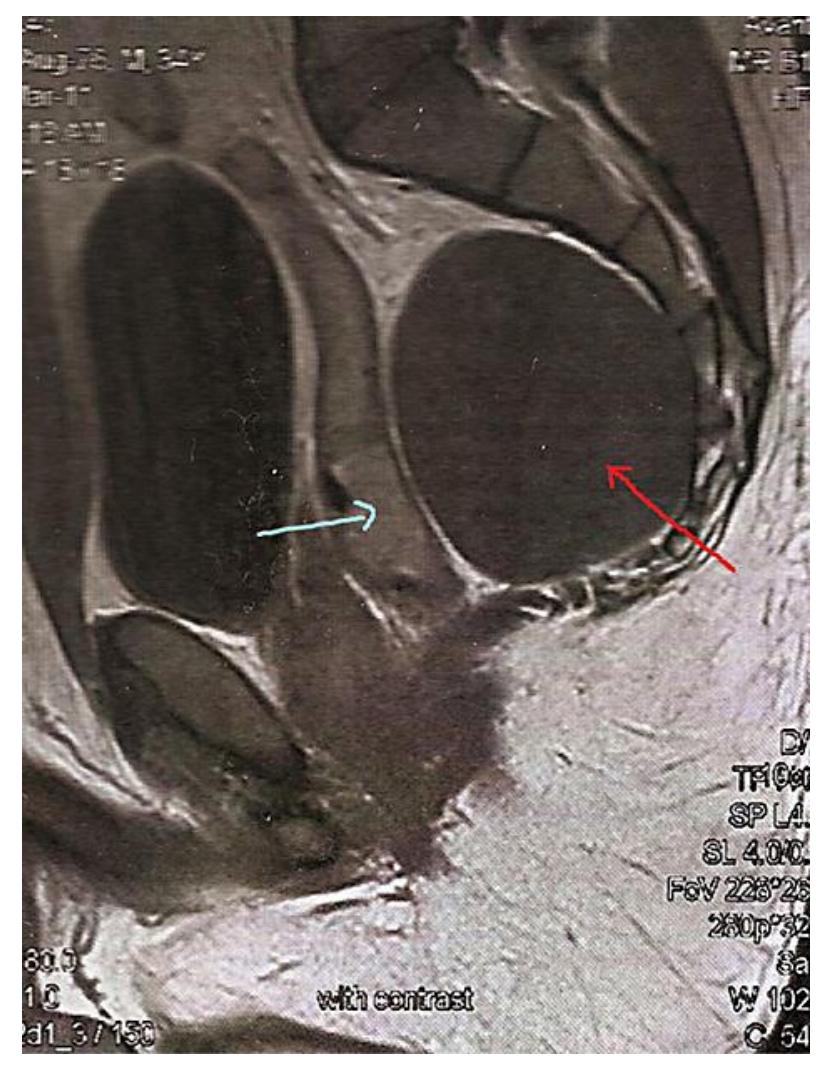

Fig. 2. Sagittal T1-weighted MRI image. A presacral tumor with low signal intensity is shown (red arrow). A fat plane can be seen between the tumor and the rectum, indicating that infiltration is not present (blue arrow). 


\section{Case Reports in Oncology}

\begin{tabular}{l|l}
\hline Case Rep Oncol 2013;6:561-568 & \\
\hline DOI: 10.1159/000356707 & $\begin{array}{l}\text { ○ 2013 S. Karger AG, Basel } \\
\text { www.karger.com/cro }\end{array}$ \\
\hline
\end{tabular}

Vardas et al.: Presacral Ganglioneuroma: Diagnostic Considerations and Therapeutic Strategy

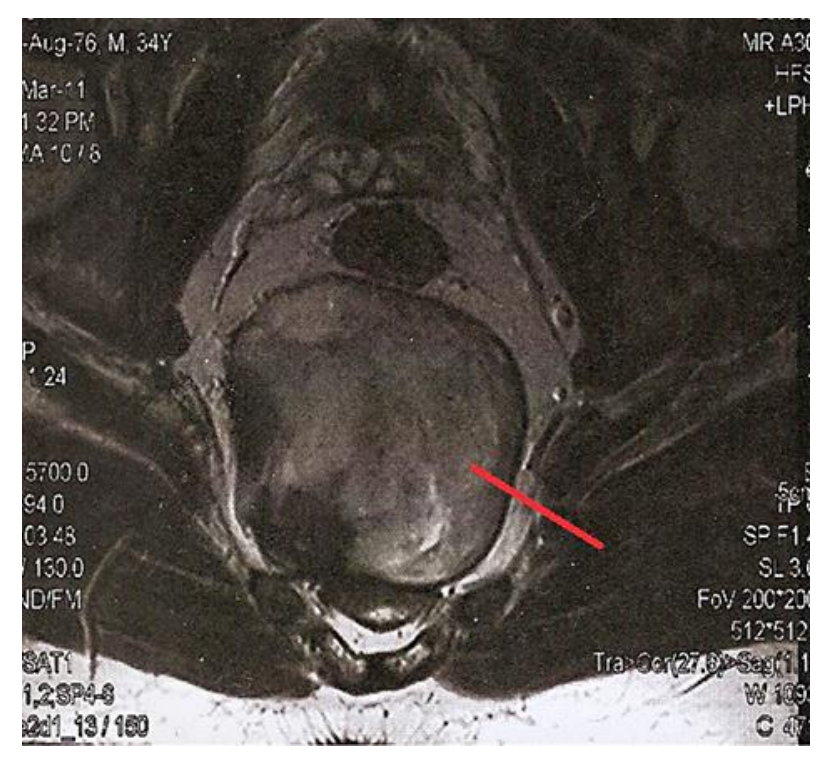

Fig. 3. Axial T2-weighted MRI image. An inhomogeneous compartmentalized solid tumor with cystic components is illustrated.

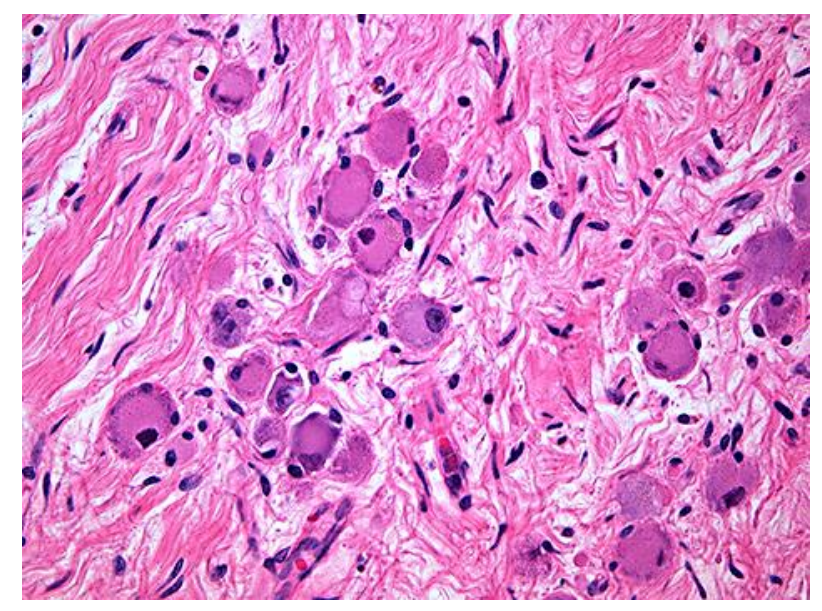

Fig. 4. Histopathologic findings. The tumor contains small clusters of mature ganglion cells surrounded by a Schwann cell-rich stroma $(\mathrm{HE} \times 400)$. 